\title{
TRATADO DE MEDICINA LEGAL PELO \\ Dr. Sousa Lima
}

Ao que escrevi relativamente o Tratado de $\mathrm{Me}$ dicina Legal do illustre Prof. Sousa Lima, publicado na «Imprensa Medica» desta Capital e transcripto nesta Revista, respondeu-me elle pelo mesmo jornal.

E como reputo ser uma substanciosa licção aos que se interessam pelo assumpto, transcrevo-a tambem, prestando não só um serviço como rendendo assignalada homenagem ao benemerito professor, gloria das lettras patrias.

S. Paulo, io de Fevereiro de 1906.

Dr. Amancio de Carvalho.

\section{MEDICINA LEGAL}

A pROPOSITO

DO MEU TRATAdO DE MEDICINA LEGAL

PELO

DR. AGOSTINHU J. DE SOUZA IIMA

Lente jubilado de Medicina Legal

O muito e merecido apreço que dedico ao meu distincto e particular amigo Dr. Amancio de Carvalho, 